\title{
Moisture content of high-straw dry cow diets affects intake, health, and performance of transition dairy cows
}

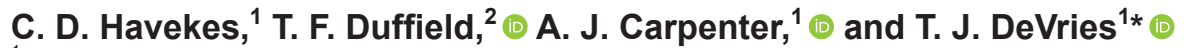 \\ ${ }^{1}$ Department of Animal Biosciences, University of Guelph, Guelph, Ontario, N1G 2W1, Canada \\ ${ }^{2}$ Department of Population Medicine, University of Guelph, Guelph, Ontario, N1G 2W1, Canada
}

\begin{abstract}
The objective of this study was to determine the effect of adding water to a high-straw dry cow diet on feeding behavior, health, and performance of dairy cows. Holstein cows $(\mathrm{n}=40)$ entering their second or greater lactation were enrolled at dry off $(\sim 45 \mathrm{~d}$ before expected calving) and assigned to 1 of 2 dietary treatments, consisting of a high-straw dry cow total mixed ration [TMR; $36 \%$ wheat straw, $41 \%$ corn silage, $23 \%$ pellet, on a dry matter (DM) basis, formulated for $11.6 \%$ crude protein, $1.35 \mathrm{Mcal} / \mathrm{kg}$ net energy for lactation] with (1) no water $(\mathrm{CON} ; \mathrm{n}=20$; $\mathrm{DM}=$ $53.4 \%$ ) or (2) water added to decrease the DM by $\sim 10$ percentage points (wet diet, $\mathrm{WD} ; \mathrm{n}=20$; $\mathrm{DM}$ $=45.4 \%$ ). Upon calving, all cows were fed the same lactating TMR (45.2\% DM, $14.9 \%$ crude protein, 1.68 $\mathrm{Mcal} / \mathrm{kg}$ net energy for lactation) and followed for 28 d. Dry matter intake, feeding behavior, and rumination activity were recorded automatically. Fresh TMR and orts samples were collected $2 \times /$ wk to determine differences in sorting. A particle separator was used to separate feed samples into 4 fractions: long $(>19 \mathrm{~mm})$, medium $(<19,>8 \mathrm{~mm})$, short $(<8,>4 \mathrm{~mm})$, and fine $(<4 \mathrm{~mm})$ particles. Feed sorting was calculated as actual intake of each particle fraction expressed as a $\%$ of predicted intake. Cows fed WD had greater DM intake during the dry period than cows fed $\mathrm{CON}(\mathrm{CON}=13.4$ $\pm 0.24, \mathrm{WD}=14.2 \pm 0.24 \mathrm{~kg} / \mathrm{d}$ ), but rumination did not differ $(\mathrm{CON}=522.2 \pm 8.48, \mathrm{WD}=518.5 \pm 8.69$ $\mathrm{min} / \mathrm{d}$ ) between treatments. Cows fed WD tended to consume their feed faster $(\mathrm{CON}=0.08 \pm 0.001$, WD $=0.09 \pm 0.001 \mathrm{~kg}$ of $\mathrm{DM} / \mathrm{min}$ ) compared with $\mathrm{CON}$ cows. Regardless of treatment, cows sorted against the longest ration particles, with cows fed CON sorting
\end{abstract}

Received September 7, 2019.

Accepted October 22, 2019.

*Corresponding author: tdevries@uoguelph.ca more against these $(\mathrm{CON}=81.1 \pm 2.51 \%, \mathrm{WD}=94.9$ $\pm 2.58 \%)$. Cows fed CON tended to sort more in favor of the medium particles than those fed WD $(\mathrm{CON}=$ $105.0 \pm 0.36 \%, \mathrm{WD}=104.2 \pm 0.37 \%)$. Postcalving DM intake and feeding behavior were not affected by dry diet treatment. Cows fed WD experienced a less rapid daily decline in rumen $\mathrm{pH}$ during the first $7 \mathrm{~d}$ after calving compared with those fed the CON diet. The results suggest that increasing the moisture content of high-straw dry cow diets, by adding water, may improve intake and reduce sorting against the longest ration particles, which may help promote consistency in targeted nutrients consumed during the dry period and greater rumen health in early lactation.

Key words: dry cow diet, moisture, feeding behavior, sorting

\section{INTRODUCTION}

Maintaining consistent intake of a well-balanced diet in the weeks leading up to calving may improve DMI and result in greater metabolic health postcalving (Goldhawk et al., 2009). Consistency in consumption in late gestation may be achieved through feeding of controlled-energy dry cow diets, which incorporate low nutrient density feedstuffs (e.g., wheat straw) into the diet (Janovick et al., 2011). These diets are designed to promote ad libitum intake, while controlling for energy consumption so that cows do not gain excessive body condition during the dry period (Dann et al., 2005; Janovick et al., 2011).

From a physiological standpoint, controlled-energy dry cow diets improve metabolic health postcalving (Dann et al., 2005, 2006; Janovick et al., 2011). One area of concern is the physical difference between a high-straw, lesser moisture dry cow ration and a more dense, greater moisture lactating ration. The transition between these 2 diets is inevitable, but cows may take 7 to $14 \mathrm{~d}$ to physiologically adapt to dietary changes and it may take this long for them to adjust their DMI to reflect that change (Grant et al., 2015). As such, it could be hypothesized that minimizing the severity 
of the change by manipulating characteristics, such as particle size and moisture content, of the dry cow ration to make it more similar to the lactating ration may ease that transition. Reducing straw particle size in highstraw dry cow diets has recently been demonstrated to improve DMI in the dry period and promote greater rumen and metabolic health postcalving (Havekes et al., 2020). In that work the shorter chop length of straw reduced sorting; however, it did not eliminate sorting completely (Havekes et al., 2020), suggesting that other dietary and management factors associated with these diets need to be implemented to minimize the risk of that behavior.

Controlled-energy dry cow diets typically contain a high proportion of dry forages and, thus, have lower moisture content than most lactating diets. Water addition to lactating cow rations that are low in moisture has been demonstrated to have some beneficial effects, including reduced sorting and resultant greater milk fat content (Leonardi et al., 2005). However, other researchers have reported that water addition to lactating cow rations increased sorting and decreased DMI (Miller-Cushon and DeVries, 2009; Felton and DeVries, 2010). A major difference between these studies was that Leonardi et al. (2005) had no wet forages in their diet, and therefore, the initial DM content of the diets were quite different. Leonardi et al. (2005) added water to a lactating cow ration to bring the DM content down from 84 to $64 \%$. Typically, lactating cow rations have greater moisture content $(\sim 45-55 \% \mathrm{DM})$, particularly when they contain a significant proportion of ensiled forages. The latter studies (Miller-Cushon and DeVries, 2009; Felton and DeVries, 2010) added water to lactating rations (with initial $\mathrm{DM}<58 \%$ ) to bring the DM to $\sim 45 \%$. The stability of greater moisture TMR may be influenced by VFA profiles in the silage, as well as molds and yeasts present in the feed; these factors may lead greater moisture TMR to be more prone to spoilage (Eastridge, 2006) and heating (Felton and DeVries, 2010). Therefore, it is possible that the addition of water to a diet containing a high proportion of dry forages may elicit more favorable results.

The effect of water addition to high-straw dry cow diets has not previously been explored. Thus, the objective of this experiment was to determine the effect of water addition to a high-straw dry cow diet on feed intake and feeding behavior, metabolic and rumen health, and milk production and components in early lactation. We hypothesized that the addition of water would improve DMI and reduce feed sorting during the dry period, and would improve rumen and metabolic health across the transition period, as well as improve milk production postcalving.

\section{MATERIALS AND METHODS}

\section{Animals and Housing}

Forty Holstein cows (parity $=1.9 \pm 1.04$; mean \pm SD) were used in this study, which took place at the University of Guelph Elora Research Station-Dairy Facility (Elora, ON, Canada). At approximately $45 \mathrm{~d}$ before expected calving $($ actual $=43.1 \pm 5.55 \mathrm{~d}$ ), cows were dried off and enrolled in the study. The use of cows and experimental procedures complied with the guidelines of the Canadian Council on Animal Care (2009) and were approved by the University of Guelph Animal Care Committee (protocol \#3628).

During the dry period, cows were housed in 1 of 2 dry cow pens and trained to eat out of individually assigned automated feed bins (Insentec, B.V., Marknesse, the Netherlands). Throughout the duration of the trial, both pens contained cows that were receiving either of the treatment diets. The dry cow pens each had 12 automated feed bins, 24 freestalls (mattress base bedded with chopped wheat straw), and 2 water troughs. The stocking density of the pens never exceeded 12 cows, ensuring each cow had access to their own lying stall and automated feed bin. Upon signs of calving, cows were moved to an individual maternity pen (3.5 $\times 4.9 \mathrm{~m}$ ) where they had individual access to feed and water. Cows were in the maternity pen for $3.6 \pm 3.7$ $\mathrm{d}$ before calving and $4.7 \pm 1.9 \mathrm{~d}$ after calving. After calving, cows were milked in their individual maternity pen using a portable milking system. After leaving the maternity pens, cows were moved to a lactating pen where they again were assigned and trained to an individual automated feed bin. The lactating pen had 15 automated feed bins, 30 free stalls, and 2 water troughs. The stocking density never exceeded $100 \%$, which ensured that all cows had access to their own feed bin and lying stall. Cows were milked in a rotary milking parlor (DeLaval, Tumba, Sweden) $2 \times / \mathrm{d}$ at 0430 and $1615 \mathrm{~h}$.

\section{Experimental Design}

Sample size and power analyses were used to calculate (as per Morris, 1999) the minimum number of replicates needed per treatment $(n=20)$ to detect a $10 \%$ level of observed mean difference for the primary outcome variables, including DMI, feeding behavior, and feed sorting. Estimates of variation for these variables were based on previously reported values (Coon et al., 2018; Dancy et al., 2019; Havekes et al., 2020).

Upon dry off, cows were randomly assigned, within pen, to 1 of 2 dietary treatments (Table 1 ), a dry cow TMR with (1) no water added $(\mathbf{C O N} ; \mathrm{n}=20)$, or $(2)$ 
water added to decrease the DM by $\sim 10$ percentage points (wet diet, WD; $\mathrm{n}=20$ ). Treatment allocation was balanced for parity and previous 305-d milk production $(10,419 \pm 1,541 \mathrm{~kg})$. Both treatment diets were formulated using Agricultural Modeling and Training Systems (AMTS.Cattle.Professional 4.10.5, New York, NY) to target an energy consumption of $20.8 \mathrm{Mcal} /$ cow per $\mathrm{d}$ of $\mathrm{NE}_{\mathrm{L}}(32.7 \mathrm{Mcal} / \mathrm{cow} / \mathrm{d}$ of $\mathrm{ME})$ and were fed for ad libitum intake for the entire dry period. Dry cow diets were formulated to target a negative DCAD value of $-176 \mathrm{mEq} / \mathrm{kg}$ and urine $\mathrm{pH}$ was routinely measured to monitor effectiveness of the DCAD program. Diets were formulated to target a chloride level of $0.83 \%$ of the ration DM. Wheat straw included in the dry diet was chopped using a bale processor (Haybuster Model H-1150, Jamestown, ND) using a 2.54-cm screen. A base diet containing corn silage, straw, and dry cow concentrate was prepared in a mixer wagon (Jaylor Model 5572, Jaylor Fabricating, Orton, ON, Canada) and then transferred to individual feed carts (Super Data Ranger, American Calan, Northwood, NH). The CON diet was then fed as is, whereas for $\mathrm{WD}$, water was then added to decrease the DM by $\sim 10$ percentage points. The diet was continuously mixed as the water was added and continued to be mixed for $\sim 3$ to $5 \mathrm{~min}$ afterward. While the water was being added to the $\mathrm{WD}$, the CON diet continued to mix in the feed cart to ensure mixing time was similar across treatments. The 2 dry cow TMR were both fed $2 \times / d$ to ensure automated feed bins were not overflowing with feed. Dry cows were fed $50 \%$ their daily feed between 0900 and $1000 \mathrm{~h}$ and the other $50 \%$ between 1500 and 1600 h. The total amount of feed offered was adjusted daily to target $10 \%$ refusals per bin (actual $=16.4 \pm 11.8 \%$, on a DM basis). The dry cow bins were cleaned out daily at approximately $0900 \mathrm{~h}$. After calving, all cows were fed the same lactating TMR (Table 1) $1 \times / \mathrm{d}$ between 0800 and $0900 \mathrm{~h}$. The total amount of lactating feed offered was adjusted daily to target approximately $10 \%$ refusals per bin (actual $=13.1 \pm 11.32 \%$, on a DM basis). The lactating diet was formulated to meet the nutrient requirements of dairy cows producing 36 $\mathrm{kg} / \mathrm{d}$ (NRC, 2001), and cows were monitored for $28 \mathrm{~d}$ postcalving.

\section{Behavioral Data Collection}

Feeding behavior and DMI were monitored using the automated feed bins, as validated by Chapinal et al. (2007). From the recorded data, the duration of each visit to the feed bin, the amount of feed consumed (start weight - end weight) during each visit, and the rate of consumption for each visit were calculated. These data were then summarized to calculate DMI $(\mathrm{kg} / \mathrm{d})$, time spent feeding $(\mathrm{min} / \mathrm{d})$, and feeding rate $(\mathrm{kg} / \mathrm{min})$. Individual feeding bouts were combined and separated into meals using a meal criterion (i.e., the minimum duration of time between meals) calculated for each cow. Meal criteria for the dry period and lactating period were calculated for each cow using methods described by DeVries et al. (2003); a software package (MIX 3.1.3; MacDonald and Green, 1988) was used to fit normal distributions to the frequency of $\log _{10^{-}}$ transformed intervals of time between feeding visits. If the interval of time between 2 feed bin visits exceeded the determined meal criterion, this was classified as a different meal. The number of different meals in a day was termed meal frequency (no./d). Total meal time was the time between the start of the first bin visit until the end of the last bin visit, excluding all of the nonfeeding intervals greater than the length of the meal criterion. Meal length (min/meal) was calculated as the total meal time divided by the meal frequency. Finally, meal size $(\mathrm{kg} / \mathrm{d})$ was calculated as daily DMI divided by the meal frequency.

An electronic monitoring system (HR-TAG-LD, SCR Engineers Ltd., Netanya, Israel) was used in this study to monitor rumination activity, as validated by Schirmann et al. (2009). Rumination data loggers, attached to a nylon collar, were fitted to each cow before enrollment. Throughout the entire duration of the dry period and for $4 \mathrm{wk}$ postcalving, rumination activity was monitored $24 \mathrm{~h} / \mathrm{d}$. The system contained a radio frequency reader, which allowed data from the collars to be continuously uploaded to the control unit. These data, stored in 2-h intervals, were used to determine total time spent ruminating throughout each day.

\section{Health Data Collection}

At the time of enrolment, 14 and $7 \mathrm{~d}$ before calving, as well as 7 and $25 \mathrm{~d}$ postcalving, cow BW was recorded using a walk-over scale (DeLaval) and BCS was visually assessed and recorded using a 5-point scale, as described by Wildman et al. (1982). One observer assessed BCS for the entire duration of the trial. All measurements were taken before feed delivery $(1000 \mathrm{~h}$ for dry cows and $0900 \mathrm{~h}$ for lactating cows).

Wireless telemetry boluses (eBolus, eCow Ltd., Devon, UK) were used to measure reticulorumen $\mathrm{pH}$ (as validated by Falk et al., 2016). Before calving, the boluses were administered to 30 cows orally using a balling gun $(\mathrm{CON}, \mathrm{n}=15$; WD, $\mathrm{n}=15)$. Data consisted of reticulorumen $\mathrm{pH}$ data points on 15-min intervals 24 $\mathrm{h} / \mathrm{d}$ throughout the trial period. Data were downloaded weekly and amalgamated into a continuous record for 
each individual cow. Time spent below a $\mathrm{pH}$ threshold of 5.8 and 6.0 and area under the curve (AUC) at a 5.8 and $6.0 \mathrm{pH}$ threshold were then calculated, along with daily mean, minimum, and maximum $\mathrm{pH}$ values. Values for AUC were also standardized for intake by dividing DMI for each day for each cow.
Blood BHB and glucose measurements were taken on $\mathrm{d}-14,-7,1,4,7,10,13,19$, and 25 and measured using an electronic handheld device (FreeStyle Precision Neo, Abbott Diabetes Care, Saint Laurent, QC, Canada), as validated by Kanz et al. (2015) and Wittrock et al. (2013), respectively. Only the sample

Table 1. Ingredient and chemical composition (mean $\pm \mathrm{SD}$ ) of the treatment dry cow and the lactating cow $\mathrm{TMR}^{1}$

\begin{tabular}{|c|c|c|c|}
\hline Composition & $\mathrm{CON}$ & WD & Lactating diet \\
\hline \multicolumn{4}{|l|}{ Ingredient ( $\%$ of $\mathrm{DM})$} \\
\hline Corn silage $^{2}$ & 41 & 41 & 30 \\
\hline Wheat straw ${ }^{3,4}$ & 36 & 36 & 2 \\
\hline Alfalfa haylage $^{5}$ & - & - & 30 \\
\hline High-moisture corn ${ }^{6}$ & - & - & 24 \\
\hline Dry cow supplement ${ }^{7}$ & 23 & 23 & - \\
\hline Lactating cow supplement ${ }^{8}$ & - & - & 14 \\
\hline \multicolumn{4}{|l|}{ Chemical composition } \\
\hline $\mathrm{DM}(\%)$ & $53.5 \pm 3.02$ & $45.4 \pm 2.92$ & $45.0 \pm 1.92$ \\
\hline $\mathrm{CP}(\%$ of $\mathrm{DM})$ & $10.7 \pm 0.76$ & $10.8 \pm 0.74$ & $14.9 \pm 0.58$ \\
\hline $\mathrm{ADF}(\%$ of $\mathrm{DM})$ & $32.1 \pm 1.13$ & $31.3 \pm 0.61$ & $19.9 \pm 1.35$ \\
\hline NDF ( $\%$ of DM) & $49.7 \pm 1.71$ & $49.4 \pm 1.22$ & $29.6 \pm 2.0$ \\
\hline TDN (\% of DM) & $63.9 \pm 2.43$ & $64.5 \pm 1.31$ & $73.4 \pm 1.99$ \\
\hline Lignin (\% of DM) & $3.6 \pm 0.34$ & $3.4 \pm 0.20$ & $2.7 \pm 0.31$ \\
\hline Starch (\% of DM) & $16.1 \pm 0.98$ & $16.3 \pm 1.52$ & $28.3 \pm 1.76$ \\
\hline Fat $(\%$ of DM) & $2.1 \pm 0.34$ & $2.3 \pm 0.21$ & $3.7 \pm 0.47$ \\
\hline $\operatorname{Ash}(\%$ of $\mathrm{DM})$ & $7.4 \pm 0.36$ & $7.7 \pm 0.51$ & $6.6 \pm 0.35$ \\
\hline $\mathrm{Ca}(\%$ of $\mathrm{DM})$ & $1.2 \pm 0.11$ & $1.3 \pm 0.21$ & $0.9 \pm 0.06$ \\
\hline $\mathrm{P}(\%$ of $\mathrm{DM})$ & $0.3 \pm 0.02$ & $0.3 \pm 0.03$ & $0.45 \pm 0.02$ \\
\hline $\mathrm{K}(\%$ of $\mathrm{DM})$ & $1.0 \pm 0.10$ & $1.1 \pm 0.12$ & $1.5 \pm 0.11$ \\
\hline $\mathrm{Na}(\%$ of $\mathrm{DM})$ & $0.1 \pm 0.02$ & $0.1 \pm 0.02$ & $0.4 \pm 0.03$ \\
\hline $\mathrm{Mg}(\%$ of $\mathrm{DM})$ & $0.4 \pm 0.04$ & $0.5 \pm 0.05$ & $0.5 \pm 0.02$ \\
\hline $\mathrm{ME}(\mathrm{Mcal} / \mathrm{kg}$ of DM) & $2.12 \pm 0.02$ & $2.12 \pm 0.02$ & $2.57 \pm 0.02$ \\
\hline $\mathrm{NE}_{\mathrm{L}}(\mathrm{Mcal} / \mathrm{kg}$ of $\mathrm{DM})$ & $1.45 \pm 0.02$ & $1.46 \pm 0.01$ & $1.68 \pm 0.03$ \\
\hline
\end{tabular}

${ }^{1} \mathrm{CON}=$ dry cow TMR with $53.5 \% \mathrm{DM}$; WD = dry cow TMR with $45.4 \% \mathrm{DM}$.

${ }^{2}$ Corn silage had a DM of $33.8 \%$ and chemical composition (DM basis) of $7.4 \pm 0.49 \% \mathrm{CP}, 22.0 \pm 1.33 \% \mathrm{ADF}$, and $40.6 \pm 0.03 \%$ NDF. Particle size distribution $(\%$ of DM) $=21.3 \pm 10.56 \%$ long $(>19 \mathrm{~mm}), 61.7 \pm 10.68 \%$ medium $(<19,>8 \mathrm{~mm}), 9.8 \pm 0.55 \%$ short $(<8,>4 \mathrm{~mm})$, and $7.2 \pm 2.63 \%$ fine $(<4 \mathrm{~mm})$ particles.

${ }^{3}$ Dry ration straw (chopped with a $2.54-\mathrm{cm}$ screen) had a DM of $90.3 \%$ and chemical composition (DM basis) of $5.6 \pm 0.50 \% \mathrm{CP}, 51.2 \pm 2.57 \% \mathrm{ADF}$, and $78.4 \pm 2.35 \% \mathrm{NDF}$. Particle size distribution $(\% \mathrm{DM})=3.0 \pm$ $2.62(>19 \mathrm{~mm}), 35.9 \pm 4.78 \%$ medium $(<19,>8 \mathrm{~mm}), 26.7 \pm 3.86 \%$ short $(<8,>4 \mathrm{~mm})$, and $33.6 \pm 9.22 \%$ fine $(<4 \mathrm{~mm})$ particles.

${ }^{4}$ Lactating straw had a DM of $88.0 \%$ and chemical composition (DM basis) of $5.6 \pm 0.23 \% \mathrm{CP}, 51.7 \pm 0.60 \%$ $\mathrm{ADF}$, and $80.5 \pm 0.39 \%$ NDF. Particle size distribution $(\% \mathrm{DM}) 13.4 \pm 7.67 \%$ long $(>19 \mathrm{~mm}), 39.1 \pm 6.34 \%$ medium $(<19,>8 \mathrm{~mm}), 21.5 \pm 3.81 \%$ short $(<8,>4 \mathrm{~mm})$, and $26.0 \pm 5.46 \%$ fine $(<4 \mathrm{~mm})$ particles.

${ }^{5}$ Alfalfa haylage had a DM of $38.2 \%$ and chemical composition (DM basis) of $18.7 \pm 0.96 \% \mathrm{CP}, 32.7 \pm 0.41 \%$ $\mathrm{ADF}$, and $40.2 \pm 0.27 \%$ NDF. Particle size distribution $(\% \mathrm{DM})=27.5 \pm 5.82$ long $(>19 \mathrm{~mm}), 55.0 \pm 7.25 \%$ medium $(<19,>8 \mathrm{~mm}), 9.7 \pm 1.33 \%$ short $(<8,>4 \mathrm{~mm})$, and $7.8 \pm 1.33 \%$ fine $(<4 \mathrm{~mm})$ particles.

${ }^{6}$ High-moisture corn had a DM of $71.0 \%$ and chemical composition (DM basis) of $9.6 \pm 0.22 \% \mathrm{CP}, 2.7 \pm 0.34 \%$ $\mathrm{ADF}$, and $7.8 \pm 0.49 \% \mathrm{NDF}$.

${ }^{7}$ Supplied by Floradale Feed Mill Ltd. (Floradale, Ontario, Canada) including ingredients (as fed): $24.0 \%$ soybean meal, $13.0 \%$ Animate (Phibro, Teaneck, NJ), 13.0\% beet pulp, 10.0\% high bypass soybean meal, $10 \%$ ground soy hulls, $9.0 \%$ limestone calcium carbonate, $5.96 \%$ bran, $4.8 \%$ canola, $3.0 \%$ molasses, $1.60 \%$ calcium sulfate, 1.4\% Diamond V Yeast XP (Diamond V, Cedar Rapids, IA), 1.0\% inorganic dry premix, 0.95\% magnesium oxide, $0.75 \%$ integral, $0.75 \%$ fine salt, $0.6 \%$ monocalcium phosphate, $0.15 \%$ granular sulfur, $0.04 \%$ Rumensin/Coban (Elanco, Greenfield, IN). Dry cow supplement had a DM of $91.2 \%$ and chemical composition (DM basis) of $26.3 \pm 0.70 \% \mathrm{CP}, 13.7 \pm 0.42 \% \mathrm{ADF}$, and $25.1 \pm 0.75 \% \mathrm{NDF}$.

${ }^{8}$ Supplied by Floradale Feed Mill Ltd. including ingredients (as fed): $40.0 \%$ soybean meal, 30.0\% SoyPlus (Landus Cooperative, Ames, IA), $10.0 \%$ canola, $4.0 \%$ sodium sesquicarbonate, $2.9 \%$ fine salt, $2.9 \%$ limestone calcium carbonate, $2.4 \%$ wheat shorts, $1.6 \%$ magnesium oxide, $1.4 \%$ monocalcium phosphate, $1.4 \%$ Diamond V Yeast XP (Diamond V), 1.0\% tallow, 1.0\% DCAD+, $0.8 \%$ urea, 0.7\% inorganic premix, $0.6 \%$ MetaSmart (Adisseo, Alpharetta, GA), 0.2\% granular sulfur, 0.04\% Rumensin/Corban (Elanco), 0.04\% Selplex 2000 (Alltech, Nicholasville, KY). Lactating cow supplement had a DM of $90.5 \%$ and chemical composition (DM basis) of $37.8 \pm 1.29 \% \mathrm{CP}, 9.5 \pm 0.11 \% \mathrm{ADF}$, and $15.9 \pm 0.23 \% \mathrm{NDF}$. 
closest to the calving date was included for analysis (i.e., d -14 samples were only used if cows calved more than $7 \mathrm{~d}$ before expected calving date). Blood glucose levels obtained from the FreeStyle Precision Neo device were then corrected using the equation $[0.6$ $+(0.86 \times$ glucometer reading $)]$, as per Wittrock et al. (2013). Further, blood calcium, nonesterified fatty acids (NEFA), and haptoglobin were assessed on d -7 , 1 , and 7 relative to calving. For blood sampling, cows were restrained in a stall to obtain blood into a $10-\mathrm{mL}$ red top evacuated tube from the coccygeal vein. Blood collection occurred before daily feeding (1000 h for dry cows and $0900 \mathrm{~h}$ for lactating cows) throughout the study. All blood samples were left to sit at room temperature for a period of $1 \mathrm{~h}$ following collection to allow coagulation and to facilitate fibrinogen breakdown. After $1 \mathrm{~h}$, samples were centrifuged at $1,500 \times g$ at $18^{\circ} \mathrm{C}$ to separate cells from serum. For each blood sample, 1.5 $\mathrm{mL}$ of serum were placed into $3-\mathrm{mL}$ tubes and stored at $-20^{\circ} \mathrm{C}$ until the time of analysis. Serum samples were sent to the Animal Health Laboratory, University of Guelph, where they were analyzed for NEFA (reagent supplied by Randox Laboratories, Crumlin, UK), glucose (reagent supplied by Roche, Indianapolis, IN), calcium (reagent supplied by Roche), and haptoglobin (reagent created and shared by the J.G. Skinner Laboratory, Veterinary Investigation Centre, Aberdeen, UK) using a photometric test on the Roche Cobas 6000 c501 instrument (Roche).

\section{Milk Yield and Components}

Following calving, milk yield was recorded at every milking in the milking parlor (DeLaval) for the 4-wk postcalving period. Milk samples were collected from each cow, at each milking, on 2 consecutive days per week starting at 5 DIM. Hence, 2 samples were taken on $\mathrm{d} 5,6,12,13,19,20,26$, and 27 . These samples were sent to a DHI testing laboratory (CanWest DHI, Guelph, ON, Canada) for component analysis (fat, protein, MUN, and SCC) using a Fourier Transform Infrared full spectrum analyzer (Milkoscan FT+ and Milkoscan 6000; Foss, Hillerod, Denmark). One value per cow on each sampling day was obtained by calculating averages and adjusting values based on milk weights per milking.

Milk composition samples were used to determine the yield of $4 \%$ FCM $(\mathrm{kg} / \mathrm{d})$, calculated as $[0.4 \times$ milk yield $(\mathrm{kg} / \mathrm{d})]+[15.0 \times$ fat yield $(\mathrm{kg} / \mathrm{d})](\mathrm{NRC}, 2001)$. Energy-corrected milk was calculated as follows: ECM $(\mathrm{kg} / \mathrm{d})=(0.327 \times \mathrm{kg}$ of milk $)+(12.95 \times \mathrm{kg}$ of fat $)$ $+(7.2 \times \mathrm{kg}$ of protein) (Tyrrell and Reid, 1965). Efficiency of milk production was calculated as kilograms of milk, $4 \%$ FCM yield, and ECM yield per kilogram of DMI per cow.

\section{Feed Sampling and Analysis}

Throughout the study, samples of each diet (dry treatment and lactating diets) were taken in duplicate $2 \times /$ wk: 1 sample was collected to determine DM and chemical composition, and the other sample was collected to determine particle size distribution. Samples of the TMR components were also collected twice monthly for analysis of DM, chemical composition, and particle size distribution. During the dry and lactating periods, orts samples were collected $2 \times /$ wk from each cow to determine particle distribution for calculation of sorting. All feed samples were immediately frozen at $-20^{\circ} \mathrm{C}$ until further analysis.

After a 24-h period of thawing, fresh and orts TMR samples collected for particle size analysis were processed using a 4-screen Penn State Particle Separator (PSPS; Heinrichs, 2013; Maulfair and Heinrichs, 2013), which separated the sample into 4 fractions based on particle size: long $(>19 \mathrm{~mm})$, medium $(<19,>8 \mathrm{~mm})$, short $(<8,>4 \mathrm{~mm})$, and fine $(<4 \mathrm{~mm})$. Separated samples were then oven-dried at $55^{\circ} \mathrm{C}$ for $48 \mathrm{~h}$. Particle size distribution and nutrient content by particle size of the offered dry treatment diets and the lactating cow diet are presented in Table 2.

The sorting of each PSPS fraction was calculated (as per Leonardi and Armentano, 2003) by dividing the actual amount of feed consumed of each fraction by the predicted amount of feed consumed of that fraction and expressing it as a percentage. For each fraction, the actual amount consumed was calculated by subtracting the DM refused from the DM offered, as determined by the PSPS analyses. The predicted amount consumed for each fraction was calculated as the product of the DMI of the total diet multiplied by the DM percentage of that fraction in the fed TMR. If the sorting value equaled $100 \%$, then no sorting of the particle fraction occurred; a value $<100 \%$ indicated sorting against that particle size fraction, whereas a value $>100 \%$ indicated sorting in favor of that particle fraction.

Feed samples collected for nutrient composition analysis included the fresh TMR samples, feed components, and fresh TMR PSPS fractions. Following oven drying at $55^{\circ} \mathrm{C}$ for $48 \mathrm{~h}$, these samples were ground to pass through a 1-mm screen (model 4 Wiley Laboratory Mill, Thomas Scientific, Swedesboro, NJ). Ground samples, pooled by week, were then sent to A\&L Laboratory Services Inc. (London, ON, Canada) for analysis of ash $\left(550^{\circ} \mathrm{C}\right.$; AOAC International, 2000: method 942.05), ADF (AOAC International, 2000: method 973.18), 
NDF with heat-stable $\alpha$-amylase and sodium sulfite (AOAC International, 2000: method 2002.04), CP (N $\times 6.25$; AOAC International, 2000: method 990.03; Leco FP-628 Nitrogen Analyzer, Leco, St. Joseph, MI), starch (heat-stable amylase and amyloglucosidase; AOAC International, 2000: method 996.11), fat (using pet ether, AOAC International, 2000: method 920.39), lignin (using $\mathrm{ADF}$ residue and $\mathrm{H}_{2} \mathrm{SO}_{4}$ ), and minerals (using aquaregia digestion inductively coupled plasma atomic emission spectroscopy), and calculation of TDN and net energy (using NRC, 2001 equations).

\section{Statistical Analyses}

All statistical analyses were conducted using SAS 9.4 software (SAS Institute Inc., Cary, NC). One cow from the CON treatment died at d 18 due to an injury that occurred $1 \mathrm{~d}$ postcalving; her postcalving data were removed primarily because her intake was low due to injury, but also because she stayed in a maternity pen that prevented her access to an automated feed bin. One cow from the WD treatment died at d 19 due to an unknown cause, but her data were kept in all analyses until d 18. Cows were routinely tested for ketosis by farm staff using Keto-Test milk strips (KetoLac BHB, Sanwa Kagaku Kenkyusho Co., Higashi-Ku, Nagoya, Japan) starting after d 7 and treated accordingly. Due to inconsistencies in propylene glycol treatment administered by farm staff between dietary treatments, BHB and glucose measurements were only included in statistical analyses up until d 7. Due to technical failure of reticulorumen $\mathrm{pH}$ boluses, complete data sets were not available for all cows, analyses were conducted using a sample size of 25 cows $(\mathrm{CON}, \mathrm{n}=10$; WD, $\mathrm{n}=15)$. Due to technical failure of 1 rumination collar, analysis of rumination time was conducted using a sample size of 39 cows (CON, $\mathrm{n}=20$; $\mathrm{WD}, \mathrm{n}=19$ ). Significance was declared at $P \leq 0.05$ and tendencies were reported if $0.05<P \leq 0.10$. If the $P$-value of an interaction term was $\leq 0.05$, it was retained in the model; otherwise, interaction terms were disregarded. Before analyses, data were screened for normality using the UNIVARIATE procedure of SAS; most variables met the assumptions for normality except for SCC, BHB, NEFA, and haptoglobin. The natural logarithm of these variables was calculated and used to achieve normality. Additionally, time spent below a $\mathrm{pH}$ of 5.8 and 6.0, and AUC calculations were normalized using

Table 2. Particle size distribution ${ }^{1}$ (mean $\pm \mathrm{SD}$ ) and nutrient content (mean \pm SD) by particle size of the delivered experimental $\operatorname{diets}^{2}$

\begin{tabular}{|c|c|c|c|}
\hline Item & $\mathrm{CON}$ & WD & Lactating diet \\
\hline \multicolumn{4}{|c|}{$\%$ as fed retained on screen $^{1}$} \\
\hline Long & $10.2 \pm 6.38$ & $9.3 \pm 5.39$ & $9.7 \pm 4.27$ \\
\hline Medium & $54.3 \pm 6.40$ & $54.3 \pm 6.55$ & $52.8 \pm 5.50$ \\
\hline Short & $15.4 \pm 1.44$ & $17.3 \pm 1.20$ & $15.3 \pm 2.68$ \\
\hline Fine & $20.0 \pm 3.07$ & $19.1 \pm 3.25$ & $22.2 \pm 3.45$ \\
\hline \multicolumn{4}{|c|}{$\%$ DM retained on screen ${ }^{1}$} \\
\hline Long & $8.2 \pm 5.19$ & $7.5 \pm 4.41$ & $8.8 \pm 3.89$ \\
\hline Medium & $53.5 \pm 5.79$ & $54.2 \pm 6.67$ & $49.3 \pm 4.11$ \\
\hline Short & $17.2 \pm 1.98$ & $18.3 \pm 1.57$ & $16.7 \pm 1.58$ \\
\hline Fine & $21.2 \pm 3.03$ & $19.9 \pm 3.53$ & $25.2 \pm 3.45$ \\
\hline \multicolumn{4}{|c|}{$\mathrm{ADF}^{3}$ (\% of screen $\left.\mathrm{DM}\right)$} \\
\hline Long & $40.0 \pm 1.76$ & $38.0 \pm 2.24$ & $32.6 \pm 1.72$ \\
\hline Medium & $30.9 \pm 1.94$ & $30.4 \pm 0.75$ & $25.6 \pm 1.67$ \\
\hline Short & $35.5 \pm 0.87$ & $33.2 \pm 0.81$ & $15.8 \pm 0.37$ \\
\hline Fine & $28.9 \pm 1.33$ & $27.6 \pm 1.71$ & $11.6 \pm 0.25$ \\
\hline \multicolumn{4}{|c|}{$\mathrm{NDF}^{3}$ (\% of screen DM) } \\
\hline Long & $59.6 \pm 2.14$ & $59.6 \pm 4.49$ & $44.5 \pm 1.25$ \\
\hline Medium & $47.9 \pm 3.09$ & $48.5 \pm 1.78$ & $35.1 \pm 0.92$ \\
\hline Short & $54.6 \pm 0.30$ & $51.3 \pm 2.27$ & $25.1 \pm 0.44$ \\
\hline Fine & $44.4 \pm 1.99$ & $43.3 \pm 2.23$ & $18.4 \pm 0.27$ \\
\hline $\operatorname{peNDF}_{8 \mathrm{~mm}}{ }^{4}(\%)$ & $30.5 \pm 2.03$ & $30.5 \pm 2.24$ & $17.2 \pm 1.00$ \\
\hline $\operatorname{peNDF}_{4 \mathrm{~mm}} 4(\%)$ & $39.0 \pm 1.50$ & $39.6 \pm 1.75$ & $22.1 \pm 1.02$ \\
\hline
\end{tabular}

${ }^{1}$ Particle size determined by processing feed samples with the Penn State Particle Separator (Heinrichs, 2013; Maulfair and Heinrichs, 2013), which has a 19-mm screen (long), 8-mm screen (medium), 4-mm screen (short), and a pan (fine).

${ }^{2} \mathrm{CON}(\mathrm{n}=54)=$ dry cow TMR with $53.5 \%$ DM; WD $(\mathrm{n}=50)=$ dry cow TMR with $45.4 \%$ DM.

${ }^{3}$ Values were obtained from chemical analysis of TMR samples separated by particle size with the Penn State Particle Separator.

${ }^{4}$ peNDF $=$ physically effective NDF; ration NDF multiplied by sum of total $\%$ DM retained on all screens $>4$ $\mathrm{mm}\left(\mathrm{peNDF}_{4 \mathrm{~mm}}\right)$ and $>8 \mathrm{~mm}\left(\mathrm{peNDF}_{8 \mathrm{~mm}}\right)$, respectively. 
the square root function. A value of 1 was added to all values before these transformations to ensure the square root could be calculated for all data points equal to 0 . Back-transformed values of time spent below a $\mathrm{pH}$ of 5.8 and 6.0, AUC, SCC, NEFA, and haptoglobin are reported in the Results section.

To investigate the effect of dietary treatment on feed sorting, feeding behavior, DMI, rumination, reticulorumen $\mathrm{pH}$, blood metabolites, milk production, and milk composition, data were first organized by status (dry or lactating) and then summarized either by day or by week (depending on sampling frequency). Data were then analyzed using the MIXED procedure of SAS, by status, treating week or day as a repeated measure and cow as the subject of the repeated statement. The models included the fixed effects of week/day, treatment, and the week/day $\times$ treatment interaction. Previous 305-d milk production, parity, and BW were added to the milk production and component models. Enrollment BW was added as a covariate to the DMI model in the dry period, and postcalving BW was added as a covariate to the DMI model in the lactating period. Covariance structure for each model was selected on the basis of best fit according to Schwarz's Bayesian information criterion; these included compound symmetry, heterogeneous compound symmetry, first-order autoregressive, and heterogeneous first-order autoregressive. The PDIFF option was used in the LSMEANS statement for analyzing differences between treatments, within week or day, when week $x$ treatment or week $\times$ day interactions were detected. To determine the occurrence of sorting within treatments, the summarized data for each particle size were averaged by week and were tested for a difference from 100 using $t$-tests, using the previously described MIXED procedure model. Differences in particle distribution between the offered dry treatment diets were also modeled using the MIXED procedure of SAS.

To determine if there was a treatment effect on BW and BCS, models were created using the MIXED procedure, wherein BW and BCS at the start of the study, before calving, postcalving, and at the end of trial were used as dependent variables and treatment was used as a fixed effect. Changes in BW and BCS were also calculated at 3 time points: (1) from dry off to precalving, (2) from precalving to end of trial, and (3) from postcalving to the end of the trial.

Given that DMI drops in the week leading up to calving (Grummer, 1995; Drackley, 1999), the change in DMI $d-7$ to -1 was modeled. To model this change, an analysis of covariance was conducted to determine if there were significant linear, quadratic, or cubic ef- fects of day (per Schwaiger et al., 2013; DeVries et al., 2014). This was done by using the MIXED procedure of SAS. The fixed effects of treatment, day, treatment $\times$ day, day ${ }^{2}$, treatment $\times$ day $^{2}$, day ${ }^{3}$, and treatment $\times$ day $^{3}$ were tested, with the random effect of cow. Starting with the highest order term, those terms that were nonsignificant $(P>0.05)$ were removed from the model in a stepwise manner until only significant $(P \leq 0.05)$ terms remained in the model. When an interaction was significant, the lower order term was removed. Similar to DMI, the rumen environment can be altered as a result of transitioning from a low-energy to a high-energy diet (Humer et al., 2015). As such, the change in rumen $\mathrm{pH}$ in wk 1 postcalving was modeled using the same approach described above.

\section{RESULTS}

\section{Dry Period}

Differences in the percent particle distribution (on a DM basis; Table 2) of the delivered experimental diets were as follows: no detected difference was observed in percentage of long $(P=0.46)$ or medium particles $(P$ $=0.53$, the WD had a greater percentage of short particles than the CON diet $(P=0.001)$, and WD tended to have a lesser percentage of fine particles than $\mathrm{CON}$ $(P=0.06)$. Cows fed WD had greater DMI compared with cows fed CON (Table 3; Figure 1). The change in DMI in the week leading up to calving was modeled, and the fitted data indicated treatment differences for the linear coefficients $(P<0.001$; Figure 2$)$, with cows fed the CON diet experiencing a greater drop in DMI during this time period. Cows fed WD consumed more wet matter $(31.5 \pm 0.44$ vs. $25.3 \pm 0.44 \mathrm{~kg} / \mathrm{d}$; $P<0.001)$ and had greater feed water intake $(17.3 \pm$ 0.24 vs. $11.9 \pm 0.44 \mathrm{~kg} / \mathrm{d} ; P<0.001)$ during the dry period. Cows fed WD tended to eat faster than cows fed CON (Table 3). There was an interaction between treatment and meal length and meal size (Table 3); however, mean separation indicated that out of the entire dry period there was only a difference between treatments on $\mathrm{d}-18$, where cows fed the CON diet spent longer on a given meal $(P=0.01)$ and had larger meals $(P=0.03)$. The detected differences on this day likely reflects natural day-to-day variation in feeding behavior. No differences between treatments were detected in rumination time and rumination time per $\mathrm{kg}$ of DMI (Table 3). Body weight was not different between treatments at dry off $(\mathrm{CON}=783.0 \pm 86.7$ $\mathrm{kg} ; \mathrm{WD}=790.2 \pm 97.0 \mathrm{~kg} ; P=0.81)$, and regardless of treatment, cows gained $\mathrm{BW}(\mathrm{CON}=46.3 \pm 8.59$ 
Table 3. Effect of water addition to a high-straw dry cow diet fed throughout the dry period on various measures of feeding behavior recorded across the dry period and the first $28 \mathrm{~d}$ of lactation (mean $\pm \mathrm{SE}$ )

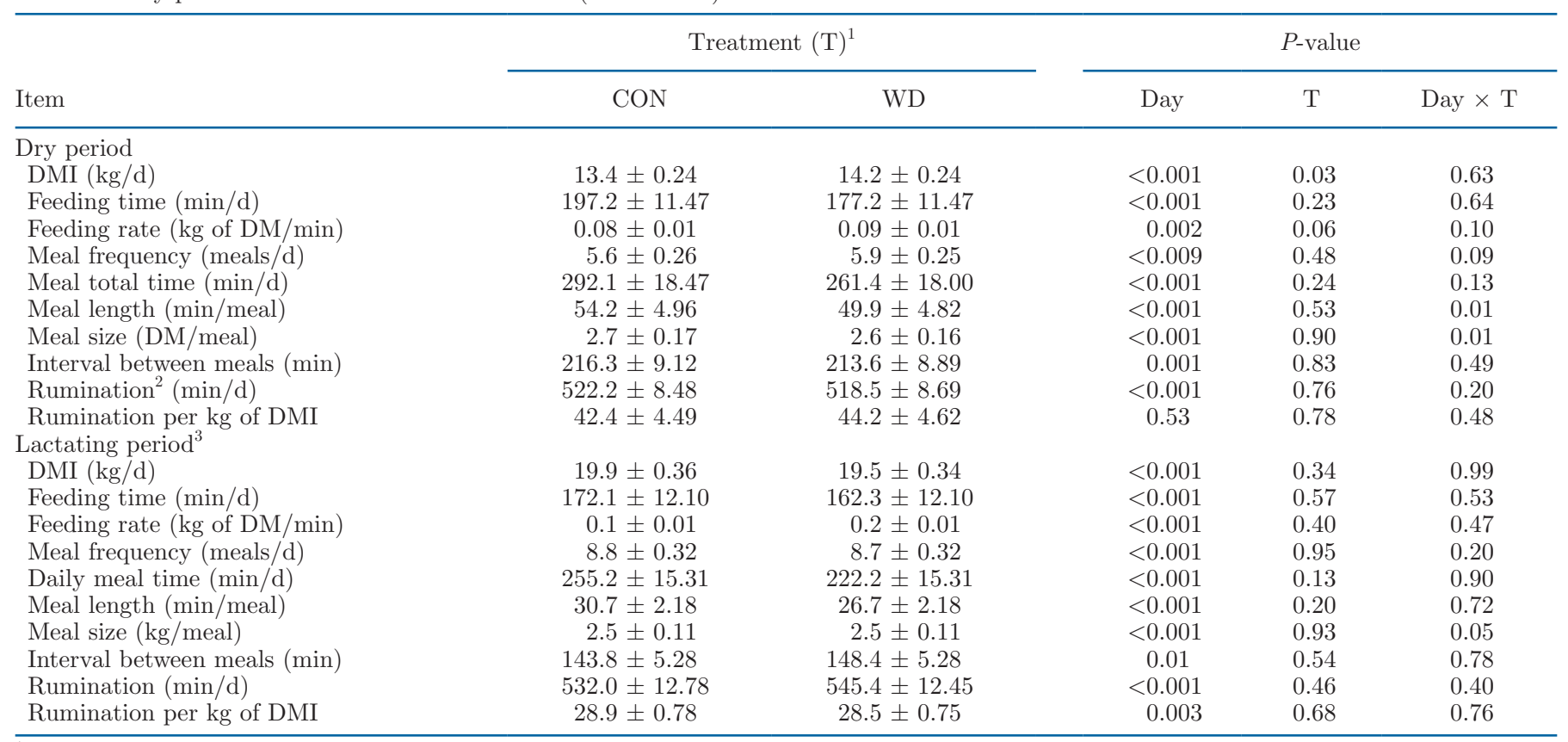

${ }^{1} \mathrm{CON}=$ dry cow TMR with $53.5 \%$ DM $(\mathrm{n}=20$ cows); WD = dry cow TMR with $45.4 \% \mathrm{DM}(\mathrm{n}=20$ cows).

${ }^{2} \mathrm{CON}, \mathrm{n}=19$ cows; $\mathrm{WD}, \mathrm{n}=19$ cows.

${ }^{3} \mathrm{CON}, \mathrm{n}=19$ cows; $\mathrm{WD}, \mathrm{n}=20$ cows.

$\mathrm{kg} ; \mathrm{WD}=50.9 \pm 8.59 \mathrm{~kg} ; P=0.71)$ and $\mathrm{BCS}(\mathrm{CON}$ $=0.2 \pm 0.06$ units; $\mathrm{WD}=0.2 \pm 0.06$ units; $P=0.24)$ throughout the dry period.

During the dry period, across treatments, cows sorted against the longest ration particles $(>19 \mathrm{~mm}$ ) (Table 4). Cows fed the CON diet sorted against these longest ration particles to a greater extent than cows fed WD. Cows fed both CON and WD sorted in favor of the medium particles $(<19,>8 \mathrm{~mm})$, but cows fed CON tended to sort more than cows fed WD. Regardless of treatment, cows did not sort for or against the short $(<8,>4 \mathrm{~mm})$ dietary particles and they sorted against the fine $(<4 \mathrm{~mm})$ dietary particles.

No effect of treatment was detected on measures of reticulorumen $\mathrm{pH}$ (Table 5) or blood parameters (Table $6)$ during the dry period.

\section{Lactating Period}

During the first $28 \mathrm{~d}$ of lactation, no difference was observed in DMI between treatments, or rumination activity (Table 3 ). A treatment by day interaction was observed for meal size (Table 3); however, mean separation indicated that there was only a difference on $\mathrm{d} 7$, whereby cows fed WD had larger meals $(P=0.03)$. This detected difference likely reflects natural day-to- day variation in feeding behavior. No other differences were detected between treatments for any other feeding behavior measures (Table 3). No difference between treatments was detected in the loss in $\mathrm{BW}(\mathrm{CON}=$ $126.0 \pm 10.17 \mathrm{~kg} ; \mathrm{WD}=142.0 \pm 10.17 \mathrm{~kg} ; P=0.20)$ and $\mathrm{BCS}(\mathrm{CON}=0.4 \pm 0.05$ units; $\mathrm{WD}=0.6 \pm 0.05$ units; $P=0.17)$.

Dry period dietary treatment did not influence sorting in the lactating period (Table 4). Regardless of treatment, cows sorted in the lactating period against the long particles, neither for nor against the medium particles, in favor of the short particles, and against the fine particles.

A treatment by week interaction was observed for mean reticulorumen $\mathrm{pH}$ (Table 5); during wk 1 cows fed WD had greater mean $\mathrm{pH}$ than $\mathrm{CON}$ cows $(\mathrm{CON}=$ $5.7 \pm 0.09, \mathrm{WD}=5.9 \pm 0.08 ; P=0.04)$. The change in mean reticulorumen $\mathrm{pH}$ for the first week postcalving was modeled, and the fitted data indicated treatment differences for the linear coefficients $(P<0.001$; Figure 3 ) with cows fed CON having a steeper decline in mean reticulorumen $\mathrm{pH}$ in the week after calving compared with cows fed WD. Further, during wk $2(\mathrm{CON}=5.7$ $\pm 0.09, \mathrm{WD}=6.0 \pm 0.08 ; P=0.09)$ and wk $3(\mathrm{CON}$ $=5.8 \pm 0.09, \mathrm{WD}=6.0 \pm 0.08 ; P=0.10)$, cows fed WD tended to have a greater mean reticulorumen $\mathrm{pH}$ 
compared with cows fed CON. A treatment by week interaction was observed for maximum reticulorumen pH (Table 5); during wk 1 postpartum, cows fed WD had greater maximum $\mathrm{pH}$ compared with cows fed $\mathrm{CON}(\mathrm{CON}=6.1 \pm 0.10, \mathrm{WD}=6.4 \pm 0.09 ; P=$ $0.05)$. A treatment by week interaction was observed for time spent below reticulorumen $\mathrm{pH}$ of 5.8 and 6.0 (Table 5), with cows fed WD tending to spend less time below a $\mathrm{pH}$ of 6.0 during wk $2(\mathrm{CON}=1,018, \mathrm{WD}=$ $630 \mathrm{~min} ; P=0.07)$ and wk $3(\mathrm{CON}=906, \mathrm{WD}=562$ $\min ; P=0.09)$ and also tending to spend less time below a $\mathrm{pH}$ of 5.8 during wk $1(\mathrm{CON}=801, \mathrm{WD}=$
$445 \min ; P=0.10)$. Last, a treatment by week interaction was observed for AUC under 5.8 standardized by DMI (Table 5); however, no differences were detected between treatments within each week $(P>0.31)$.

During the lactating period, no differences were observed between treatments for any of the blood metabolites measured (Table 6). Milk production and efficiency of production did not differ by treatment (Table 7). Also, no treatment effect was observed on milk components, MUN, or SCC (Table 7). A treatment by week interaction was observed for milk protein content (Table 7); however, no differences in milk pro-
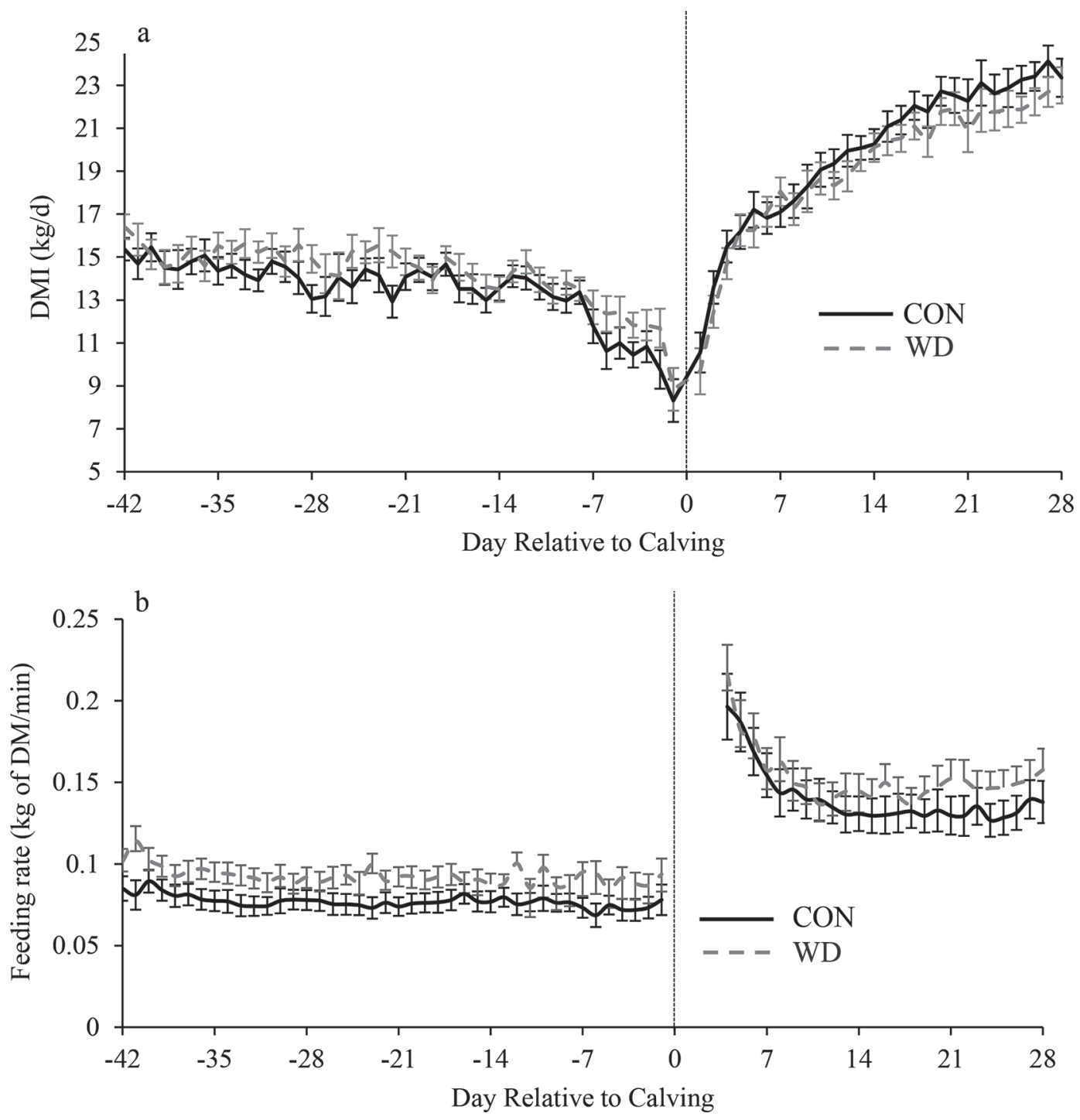

Figure 1. Mean $( \pm \mathrm{SE})$ daily (a) DMI $(\mathrm{kg} / \mathrm{d})$ and (b) feeding rate $(\mathrm{kg}$ of DM/min) for cows fed 1 of 2 dietary treatments during the dry period that differed in DM content $[\mathrm{CON}=$ dry cow TMR with $53.5 \% \mathrm{DM}(\mathrm{n}=20$ cows); WD $=$ dry cow TMR with $45.4 \% \mathrm{DM}(\mathrm{n}=20$ cows) upon calving all cows were fed the same lactating cow ration. Vertical line represents calving. 
Table 4. Effect of water addition to a high-straw dry cow diet on the sorting $(\%)^{1,2}$ of dairy cows across the dry period and in the first $28 \mathrm{~d}$ of lactation (mean $\pm \mathrm{SE}$ )

\begin{tabular}{|c|c|c|c|c|c|}
\hline \multirow[b]{2}{*}{ Item } & \multicolumn{2}{|c|}{ Treatment $(\mathrm{T})^{3}$} & \multicolumn{3}{|c|}{$P$-value } \\
\hline & $\mathrm{CON}$ & WD & Week & $\mathrm{T}$ & Week $\times \mathrm{T}$ \\
\hline \multicolumn{6}{|c|}{ Dry period } \\
\hline Long & $81.1 \pm 2.51^{*}$ & $94.9 \pm 2.58^{*}$ & 0.06 & 0.001 & 0.97 \\
\hline Medium & $105.0 \pm 0.36^{*}$ & $104.2 \pm 0.37^{*}$ & 0.003 & 0.09 & 0.95 \\
\hline Short & $100.2 \pm 0.31$ & $99.7 \pm 0.32$ & 0.17 & 0.35 & 0.92 \\
\hline Fine & $90.0 \pm 1.28^{*}$ & $88.5 \pm 1.32^{*}$ & $<0.001$ & 0.41 & 0.66 \\
\hline \multicolumn{6}{|l|}{ Lactating } \\
\hline Long & $96.3 \pm 1.32^{*}$ & $96.1 \pm 1.32^{*}$ & 0.09 & 0.94 & 0.33 \\
\hline Medium & $100.9 \pm 0.26^{*}$ & $101.1 \pm 0.26^{*}$ & $<0.001$ & 0.61 & 0.79 \\
\hline Short & $101.8 \pm 0.33^{*}$ & $102.3 \pm 0.32 *$ & 0.14 & 0.23 & 0.48 \\
\hline Fine & $97.3 \pm 0.85^{*}$ & $96.2 \pm 0.84^{*}$ & $<0.001$ & 0.34 & 0.85 \\
\hline
\end{tabular}

${ }^{1}$ Particle size determined by the Penn State Particle Separator (Heinrichs, 2013; Maulfair and Heinrichs, 2013), which has a 19-mm screen (long), 8-mm screen (medium), 4-mm screen (short), and a pan (fine).

${ }^{2}$ Sorting $\%=$ actual DMI of each particle size fraction/predicted DMI of each particle size fraction $\times 100$. For each fraction, the actual DM amount consumed was calculated by subtracting the DM refused from the DM offered, as determined by the Penn State Particle Separator analyses. The predicted amount consumed for each fraction was calculated as the product of the actual DMI of the total diet multiplied by the DM percentage of that fraction in the fed TMR. Sorting $\%=100$ means no sorting occurred, sorting $\%<100$ means sorting occurred against, and sorting $\%>100$ means sorting occurred in favor of that particle fraction.

${ }^{3} \mathrm{CON}=$ dry cow TMR with $53.5 \%$ DM $(\mathrm{n}=20$ cows $)$; WD = dry cow TMR with $45.4 \% \mathrm{DM}(\mathrm{n}=20$ cows $)$.

$* P<0.05=$ difference in sorting from $100 \%$.

tein content between treatments within each week were detected $(P>0.11)$.

\section{DISCUSSION}

Researchers have previously investigated the effect of moisture content of lactating cow rations (Miller-
Cushon and DeVries, 2009; Felton and DeVries, 2010; Fish and DeVries, 2012), but to our knowledge the current work is the first to investigate the addition of water to a dry cow ration, specifically that with a high straw inclusion rate. Specifically, it was aimed to determine if water addition to a high-straw dry cow TMR would improve DMI and reduce feed sorting during the

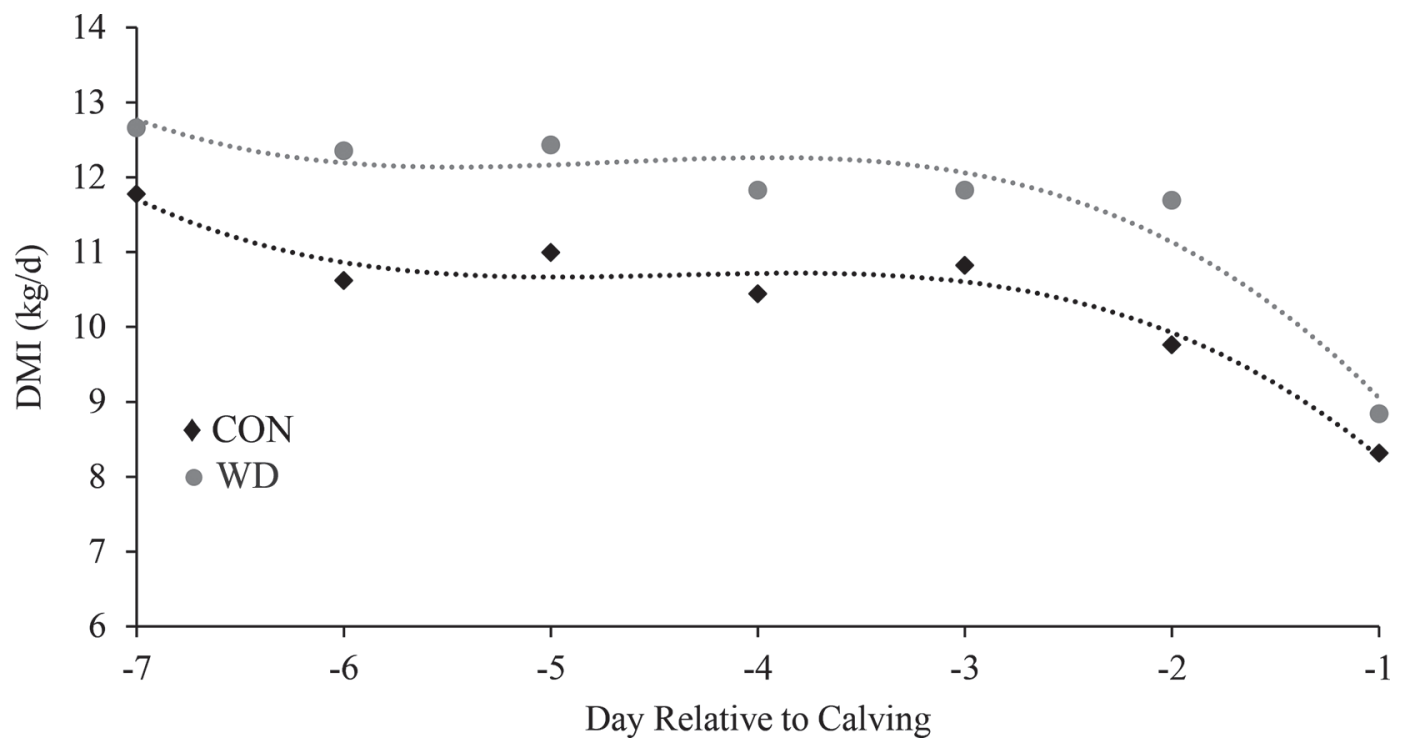

Figure 2. Mean daily DMI in the week leading up to calving when fed dry cow diets that differed in DM content $[$ CON $=$ dry cow TMR with $53.5 \% \mathrm{DM}(\mathrm{n}=20$ cows); WD = dry cow TMR with $45.4 \% \mathrm{DM}(\mathrm{n}=20$ cows)]. Trend lines were constructed using analysis of covariance $\mathrm{y}=-5.18 \mathrm{~d}-1.17 \mathrm{~d}^{2}-0.09 \mathrm{~d}^{3}+4.64\left(\mathrm{R}^{2}=0.93\right)$ for WD; $\mathrm{y}=-5.13 \mathrm{~d}-1.17 \mathrm{~d}^{2}-0.09 \mathrm{~d}^{3}+3.74\left(\mathrm{R}^{2}=0.96\right)$ for CON. 
Table 5. Effect of water addition to a high-straw dry cow diet fed throughout the dry period on measures of reticulorumen pH throughout the dry period and the first $28 \mathrm{~d}$ of lactation (mean $\pm \mathrm{SE}$ )

\begin{tabular}{|c|c|c|c|c|c|}
\hline \multirow[b]{2}{*}{ Item } & \multicolumn{2}{|c|}{ Treatment $(\mathrm{T})^{1}$} & \multicolumn{3}{|c|}{$P$-value } \\
\hline & $\mathrm{CON}$ & WD & Week & $\mathrm{T}$ & Week $\times \mathrm{T}$ \\
\hline \multicolumn{6}{|l|}{ Dry period } \\
\hline Mean & $6.2 \pm 0.07$ & $6.3 \pm 0.06$ & 0.03 & 0.43 & 0.05 \\
\hline Minimum & $5.9 \pm 0.06$ & $6.0 \pm 0.05$ & 0.09 & 0.31 & 0.17 \\
\hline Maximum & $6.5 \pm 0.08$ & $6.6 \pm 0.07$ & 0.06 & 0.38 & 0.01 \\
\hline \multicolumn{6}{|l|}{ Lactating period } \\
\hline Maximum & $6.2 \pm 0.10$ & $6.4 \pm 0.09$ & 0.04 & 0.18 & 0.005 \\
\hline \multicolumn{6}{|l|}{ Transformed data } \\
\hline $\mathrm{Sqrt}^{2} \min <6.0$ & $30.1 \pm 2.69$ & $25.4 \pm 2.29$ & $<0.001$ & 0.20 & 0.001 \\
\hline $\mathrm{Sqrt}^{2} \min <5.8$ & $22.5 \pm 3.18$ & $17.9 \pm 2.71$ & $<0.001$ & 0.28 & 0.02 \\
\hline Sqrt $^{2} \mathrm{AUC}^{3} 6.0$ & $16.5 \pm 2.28$ & $13.4 \pm 1.94$ & $<0.001$ & 0.32 & 0.01 \\
\hline Sqrt $^{2}$ AUC $^{3} 5.8$ & $10.6 \pm 2.06$ & $8.4 \pm 1.75$ & $<0.001$ & 0.43 & 0.06 \\
\hline Sqrt $^{2} \mathrm{AUC}^{3,4}$ 6.0/DMI & $4.1 \pm 0.61$ & $3.6 \pm 0.52$ & $<0.001$ & 0.58 & 0.06 \\
\hline $\mathrm{AUC}^{3,5} 5.8$ & $111(39.8,220.2)^{6}$ & $70(22.7,144.6)^{6}$ & - & - & - \\
\hline AUC $6.0^{3,4,5} / \mathrm{DMI}$ & $16(7.8,28.3)^{6}$ & $12(6.4,21.9)^{6}$ & - & - & - \\
\hline AUC $5.8^{3,4,5} / \mathrm{DMI}$ & $8(3.0,15.6)^{6}$ & $5(2.6,12.2)^{6}$ & - & - & - \\
\hline
\end{tabular}

${ }^{1} \mathrm{CON}=$ dry cow TMR with $53.5 \%$ DM $(\mathrm{n}=10$ cows); WD = dry cow TMR with $45.4 \%$ DM (n = 15 cows).

${ }^{2}$ Sqrt = square root transformation; a value of 1 was added to all values before the transformation to ensure the square root could be calculated for all data points equal to 0 .

${ }^{3} \mathrm{AUC}=$ area under the curve $(\mathrm{pH} \times \min / \mathrm{d})$.

${ }^{4} \mathrm{AUC} / \mathrm{DMI}=$ area under the curve $\mathrm{pH}<5.8$ or $6.0(\mathrm{pH} \times \min / \mathrm{d})$ divided by DMI $(\mathrm{kg} / \mathrm{d})$.

${ }^{5}$ Back-transformed AUC data.

${ }^{6} 95 \%$ CI for back-transformed data.

Table 6. Effect of water addition to a high-straw dry cow diet fed throughout the dry period on blood parameters from $7 \mathrm{~d}$ precalving and 7 $\mathrm{d}$ postcalving (mean $\pm \mathrm{SE})$

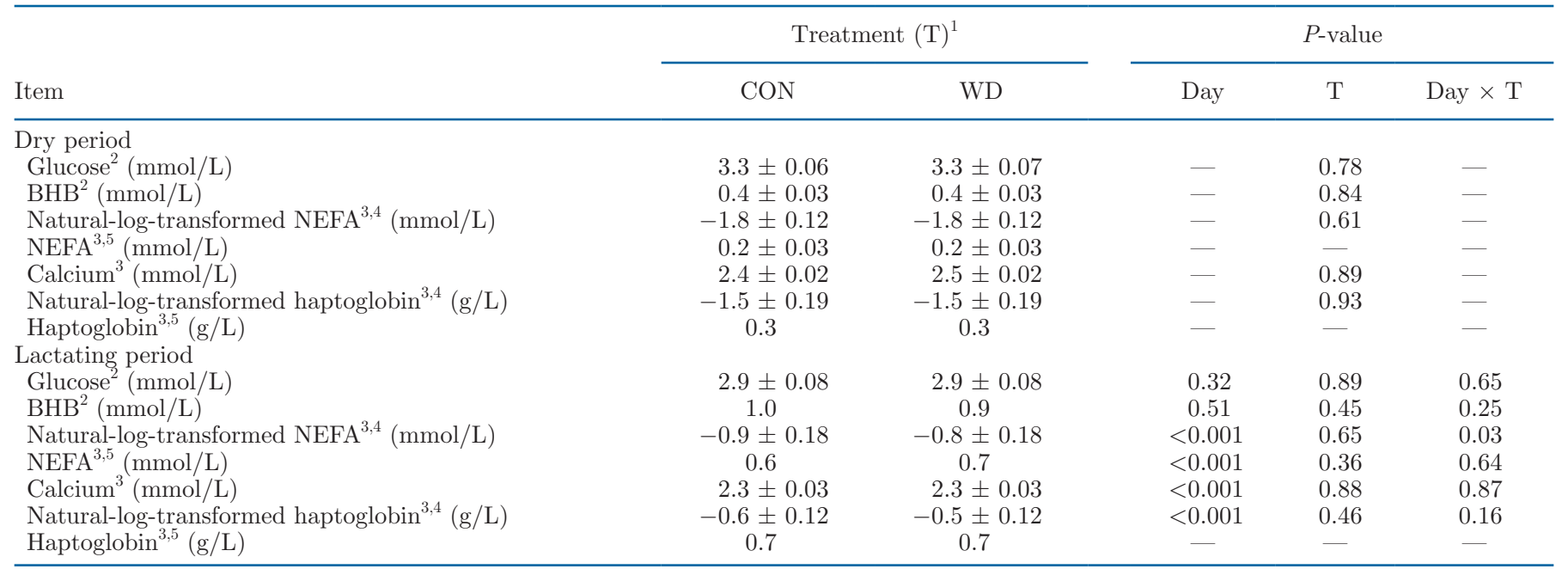

${ }^{1} \mathrm{CON}=$ dry cow TMR with $53.5 \%$ DM $(\mathrm{n}=20$ cows); WD = dry cow TMR with $45.4 \% \mathrm{DM}(\mathrm{n}=20$ cows).

${ }^{2}$ Blood samples were taken on $\mathrm{d}-7,1,4$, and 7 relative to calving.

${ }^{3}$ Blood samples taken on $\mathrm{d}-7,1$, and 7 relative to calving. NEFA $=$ nonesterified fatty acids.

${ }^{4}$ Log-transformed data.

${ }^{5}$ Back-transformed data. 


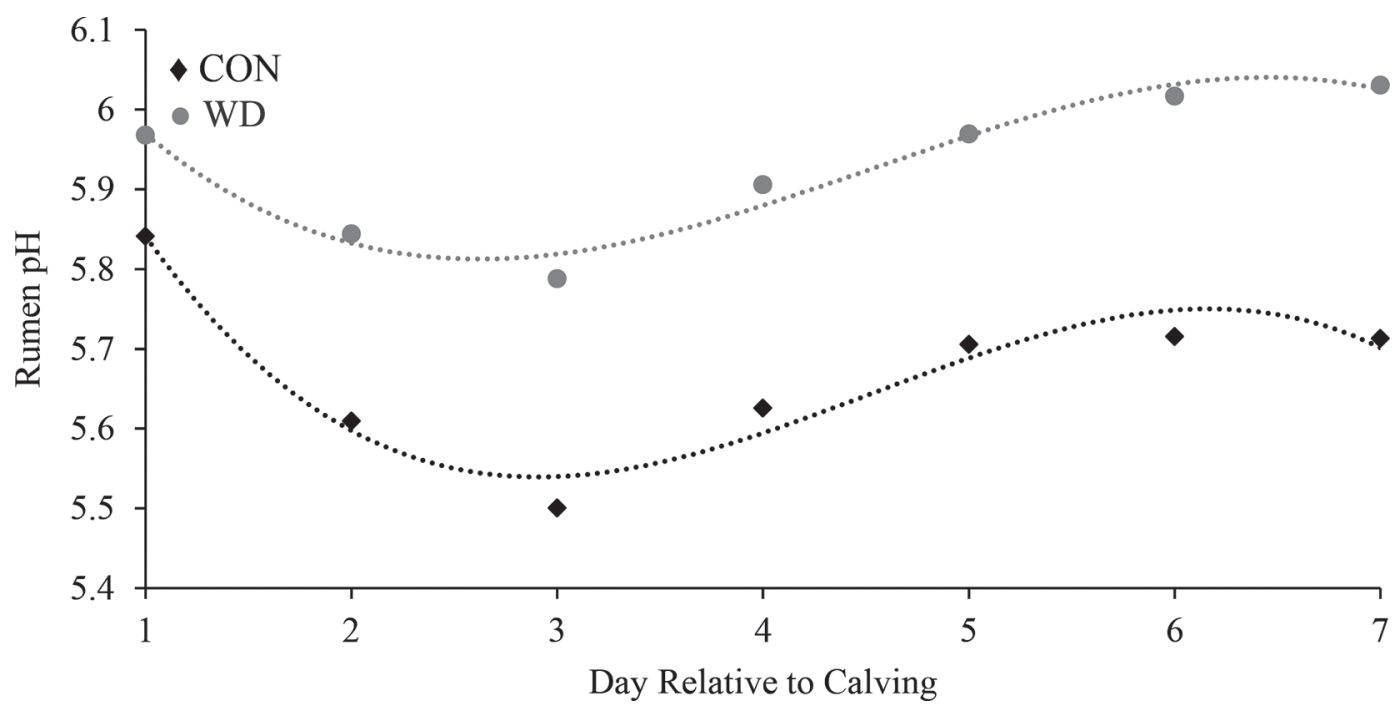

Figure 3. Mean daily reticulorumen $\mathrm{pH}$ for cows 1 wk postcalving when fed dry cow diets that differed in DM content [CON $=$ dry cow TMR with $53.5 \%$ DM $(\mathrm{n}=10$ cows); WD = dry cow TMR with $45.4 \% \mathrm{DM}(\mathrm{n}=15$ cows $)]$. Trend lines were constructed using analysis of covariance: $\mathrm{y}=-0.54 \mathrm{~d}+0.15 \mathrm{~d}^{2}-0.01 \mathrm{~d}^{3}+6.41\left(\mathrm{R}^{2}=0.96\right)$ for $\mathrm{WD} ; \mathrm{y}=-0.56 \mathrm{~d}+0.15 \mathrm{~d}^{2}-0.01 \mathrm{~d}^{3}+6.23\left(\mathrm{R}^{2}=0.94\right)$ for CON.

dry period and improve health across the transition period. In support of our hypothesis, cows fed the WD consumed more DM during the dry period than cows fed CON. Cows fed the WD also consumed more feed on an as fed-basis and, consequently, had greater feed water intake, although this clearly did not contribute to greater rumen fill, as evident by greater DMI for those cows. The rumen capacity of dairy cows is independent of gestation, which suggests that regardless of being pregnant or lactating, cows could theoretically consume the same amount of DM (Park et al., 2001). In fact, rumen water-holding capacity has been demonstrated

Table 7. Effect of water addition to a high-straw dry cow diet fed throughout the dry period on the milk production and composition of lactating dairy cows in the first $28 \mathrm{~d}$ of lactation (mean $\pm \mathrm{SE})^{1}$

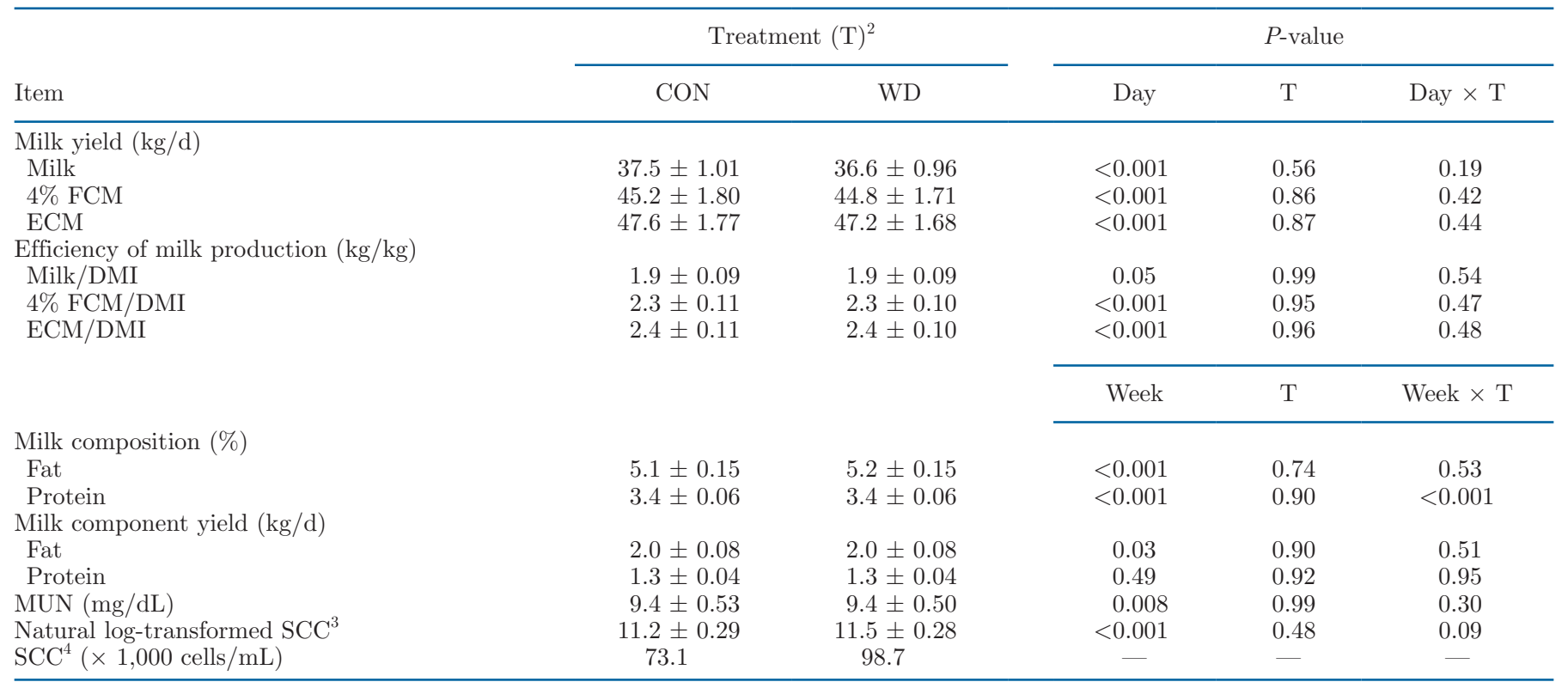

${ }^{1}$ Milk composition was tested on 2 consecutive days per week starting on $\mathrm{d} 5$ for each cow; all values were averaged by cow, by week.

${ }^{2} \mathrm{CON}=$ dry cow TMR with $53.5 \% \mathrm{DM}(\mathrm{n}=20$ cows); WD = dry cow TMR with $45.4 \% \mathrm{DM}(\mathrm{n}=20$ cows $)$.

${ }^{3}$ Somatic cell counts (cells $/ \mathrm{mL}$ ) were log-transformed, given that they did not meet the assumptions of normality.

${ }^{4}$ Back-transformed SCC data. 
to increase linearly from early to late gestation (Park et al., 2001). In some studies where water was added to lactating rations, DMI decreased (Miller-Cushon and DeVries, 2009; Felton and DeVries, 2010). It could be hypothesized that the increased bulk of feed associated with water addition to the ration may limit intake for lactating cows by increasing gut fill, but because dry cows typically have much lesser DMI than lactating cows, they have a greater capacity to handle a more water-dense ration. It is important to note, despite a 45-d dry period being at the low end of the traditional 6- to 8-wk dry period recommendation (Kok et al., 2019), it is an acceptable option (Kuhn et al., 2006), particularly with a one-group dry cow TMR. The results from this study may be applicable to other management systems targeting a longer dry period, as well as those with 2 -group feeding strategies; further research is needed to examine these potential effects.

During the dry period, cows sorted against the longest dietary particles, regardless of treatment, which was expected as cows usually sort against the longest, most fibrous particles of the diet (Miller-Cushon and DeVries, 2017). In support of our hypothesis, cows on WD sorted less against the long particle fraction than those on CON. Consistent intake of long dietary particles can promote rumen health (DeVries et al., 2008), thus it could be hypothesized that reduced sorting against the long particles may help prime the rumen for its transition onto a higher-concentrate lactating diet. Reduced sorting against the longest dietary particles is consistent with Leonardi et al. (2005), but inconsistent with Miller-Cushon and DeVries (2009) and Felton and DeVries (2010) when water was added to lactating diets. A major difference between the aforementioned studies being that Leonardi et al. (2005) did not have any ensiled forages in their diet, whereas Miller-Cushon and DeVries (2009) and Felton and DeVries (2010) did not have any dry forages in their diets. Although the overall DM content of the diets in the present study was closer to that of the diets from Miller-Cushon and DeVries (2009) and Felton and DeVries (2010), it is important to note that water addition to a diet containing primarily ensiled forages (50-60\% of total ration DM) may compromise its stability, particularly depending on the VFA profiles in the silage, as well as molds and yeasts that may be present in the feed. This has the potential to lead to increased heating and spoilage (Felton and DeVries, 2010), particularly in the wettest portion of the diet, which in both previous studies was the long particle fraction. In the present study, ensiled forage only made up $41 \%$ of the ration DM, and therefore, this dry diet may have been less likely to spoil or heat with water addition.
Furthermore, it has been suggested that water addition to TMR can help bind the smaller particles to the longer particles and reduce the sorting in favor of the smallest dietary particles (Miller-Cushon and DeVries, 2009). Although there were no differences in percent distribution of the long and medium particles across dry diets tested in the present study, the WD treatment tended to have a lesser percentage of fine particles, and had a greater percentage of short particles compared with the CON treatment. Interestingly, cows sorted against the fine fraction, which was surprising as these are usually sought-after particles (Miller-Cushon and DeVries, 2017). Similar sorting results were seen when dairy cows were fed finely chopped straw in both a lactating ration (Coon et al., 2018) and a dry cow ration (Havekes et al., 2020), suggesting that cows may prefer not to consume straw fines, which would have made up a large proportion of the fine particle fraction.

Contrary to our hypothesis, and in agreement with Havekes et al. (2020), dietary treatment in the dry period did not influence how cows sorted their diet postcalving. Sorting during early lactation, when energy demands are high, is likely more related to energy balance (DeVries et al., 2011; Moore and DeVries, 2018) than it is related to a carry-over effect from the dry period. Furthermore, because cows will sort diets more extensively where particles are easily distinguishable (Oelker et al., 2009), it is possible that the greater proportion of short and fine particles, coupled with the moisture content of the lactating ration, made it more difficult to sort. That may explain why we did not see extensive sorting of the lactating ration and any differences in that behavior between treatments.

Feeding rate tended to be faster during the dry period for cows fed the WD. To our knowledge, the only other study investigating moisture content on feeding behavior was Khan et al. (2014), where water was added to heifer diets containing a large proportion of dry forages. Similar to the present study, Khan et al. (2014) reported no differences in feeding time, meal frequency, meal size, or meal duration when water was added. Contrary to the present study, Khan et al. (2014) reported no difference in feeding rate. Interestingly, those researchers also reported no differences in sorting between treatments. The slower feeding rate for cows on the CON diet in the present study is likely explained by those cows sorting their ration more and, thus, slowing their rate of consumption. This is consistent with Greter and DeVries (2011), where it was demonstrated that increased sorting of a lactating cow TMR was associated with a slower rate of consumption of that diet. Additionally, Beauchemin et al. (2008) reported that additional salivation is required to process feeds 
with greater NDF content, such as straw. Although the NDF content of the 2 experimental diets was similar in the present study, it is possible that because the WD had additional moisture added, the cows on that diet did not need to chew the feed as long while eating to provide sufficient lubrication to facilitate swallowing.

No differences were detected between treatments for BCS and BW gain and loss, or for any blood parameters in the dry or lactating period. Cows experience little metabolic stress and relatively low energy demands during the dry period, so it is not surprising that we did not see differences between treatments during that time. However, because cows fed the $\mathrm{CON}$ diet experienced a more rapid drop in DMI in the week leading up to calving and had lesser DMI across the whole dry period, we would have expected those cows to be at greater risk for greater body fat mobilization and ketosis postcalving (Goldhawk et al., 2009). It may be that because DMI was not different between treatments postcalving, cows were able to adapt to their energy demands sufficiently, despite their differences in precalving intake.

Rumen health was not affected by dietary treatment during the dry period. The lack of difference between treatments is not surprising as cows are at low risk of ruminal acidosis when fed a high-forage diets (Stone, 2004). There was also no difference in rumination time or rumination time per kilogram of DMI; thus, we would not expect any differences in saliva production or buffering capacity between treatments. In the lactating period, cows previously fed the WD had greater mean daily reticulorumen $\mathrm{pH}$ in $\mathrm{wk} 1$, and tended to have greater mean reticulorumen $\mathrm{pH}$ in wk 2 and 3 , compared with cows fed the CON diet. Furthermore, cows previously fed the CON diet spent nearly double the amount of time with reticulorumen $\mathrm{pH}$ below 5.8 during the first week after calving compared with cows fed the WD. Greater DMI in the weeks leading up to calving may help develop rumen papillae, rumen mat formation, and the absorptive capacity of the rumen (Mertens, 1997; Kleen et al., 2003; Derakhshani et al., 2017). An increased absorptive capacity of the rumen reduces VFA accumulation and, consequently, prevents rumen $\mathrm{pH}$ from dropping too low (Kleen et al., 2003; Derakhshani et al., 2017). Thus, the more stable rumen $\mathrm{pH}$ following calving of the cows previously fed the WD is likely a result of maintaining more consistent intake in the week leading up to calving. Likewise, Havekes et al. (2020) studied the effect of forage particle size in a high-straw diet and reported similar results, whereby those cows fed a high-straw dry diet with shorter straw particle size who maintained more stable intake in the dry period also maintained more stable rumen $\mathrm{pH}$ in the week following calving. Despite the differences in rumen $\mathrm{pH}$ in the early postpartum period in the current study, we detected no differences between treatments in milk production, efficiency of milk production, or milk components. This may not be very surprising, as milk yield is primarily driven by DMI and there was no difference in DMI postcalving. Additionally, because there was no evidence of increased body fat mobilization between treatments, we would not expect to see any differences in milk fat yield or content.

\section{CONCLUSIONS}

Increasing the moisture content of a high-straw dry cow diet, through water addition, improved DMI during the dry period, resulted in less sorting of that diet, and maintained more consistent DMI in the week leading up to calving. During the first week postcalving, cows that were previously fed the dry diet with greater moisture content experienced a more stable and greater reticulorumen $\mathrm{pH}$. Overall, these results demonstrate that decreasing the DM content of a high-straw dry cow diet had positive effects on intake and feeding behavior during the dry period, as well as on postpartum rumen health.

\section{ACKNOWLEDGMENTS}

The author thanks the staff of the University of Guelph, Elora Research Station-Dairy Facility (Elora, ON, Canada), and especially to Laura Wright for all her assistance and patience while facilitating this research project. Special thanks to Kaitlyn Dancy, Meagan King, Sarah Parsons, and Sydney Moore of the University of Guelph (Guelph, ON, Canada) for their assistance with data collection. Thanks also to Bill Woodley (Woodley Dairy Direction, Stratford, ON, Canada) for his contributions to the conception of this project. This project was financially supported by a Natural Sciences and Engineering Research Council of Canada (NSERC; Ottawa, ON, Canada) Collaborative Research and Development Grant with Trouw Nutrition (Guelph, ON, Canada), as well as from the Ontario Agri-Food Innovation Alliance Research Program of the University of Guelph and the Ontario Ministry of Agriculture, Food, and Rural Affairs (Guelph, ON, Canada). Further, project equipment was supported by contributions from the Canadian Foundation for Innovation (CFI; Ottawa, Ontario, Canada) and the Ontario Research Fund (Toronto, Ontario, Canada). The authors have not stated any conflicts of interest. 


\section{REFERENCES}

AOAC International. 2000. Official Methods of Analysis. Vol. I. 17th ed. AOAC International, Arlington, VA.

Beauchemin, K. A., L. Eriksen, P. Nørgaard, and L. M. Rode. 2008. Short communication: Salivary secretion during meals in lactating dairy cattle. J. Dairy Sci. 91:2077-2081. https://doi.org/10.3168/ jds.2007-0726.

Canadian Council on Animal Care. 2009. Guidelines on: The Care and Use of Farm Animals in Research, Teaching and Testing. Canadian Council on Animal Care, Ottawa, ON, Canada.

Chapinal, N., D. M. Veira, D. M. Weary, and M. A. G. von Keyserlingk. 2007. Technical note: Validation of a system for monitoring individual feeding and drinking behavior and intake in group-housed cattle. J. Dairy Sci. 90:5732-5736. https://doi.org/ 10.3168/jds.2007-0331.

Coon, R. E., T. F. Duffield, and T. J. DeVries. 2018. Effect of straw particle size on the behavior, health, and production of early-lactation dairy cows. J. Dairy Sci. 101:6375-6387. https://doi.org/10 $.3168 /$ jds.2017-13920.

Dancy, K. M., E. S. Ribeiro, and T. J. DeVries. 2019. Effect of dietary transition at dry off on the behaviour and physiology of dairy cows. J. Dairy Sci. 102:4387-4402. https://doi.org/10.3168/ jds.2018-15718.

Dann, H. M., N. B. Litherland, J. P. Underwood, M. Bionaz, A. D'Angelo, J. W. McFadden, and J. K. Drackley. 2006. Diets during far-off and close-up dry periods affect periparturient metabolism and lactation in multiparous cows. J. Dairy Sci. 89:3563-3577. https://doi.org/10.3168/jds.S0022-0302(06)72396-7.

Dann, H. M., D. E. Morin, G. A. Bollero, M. R. Murphy, and J. K. Drackley. 2005. Prepartum intake, postpartum induction of ketosis, and periparturient disorders affect the metabolic status of dairy cows. J. Dairy Sci. 88:3249-3264. https://doi.org/10.3168/ jds.S0022-0302(05)73008-3.

Derakhshani, H., H. M. Tun, F. C. Cardoso, J. C. Plaizier, E. Khafipour, and J. J. Loor. 2017. Linking peripartal dynamics of ruminal microbiota to dietary changes and production parameters. Front. Microbiol. 7:2143. https://doi.org/10.3389/fmicb.2016.02143.

DeVries, T. J., F. Dohme, and K. A. Beauchemin. 2008. Repeated ruminal acidosis challenges in lactating dairy cows at high and low risk for developing acidosis: Feed sorting. J. Dairy Sci. 91:3958 3967. https://doi.org/10.3168/jds.2008-1347.

DeVries, T. J., L. Holtshausen, M. Oba, and K. A. Beauchemin. 2011. Effect of parity and stage of lactation on feed sorting behavior of lactating dairy cows. J. Dairy Sci. 94:4039-4045. https://doi.org/ 10.3168/jds.2011-4264.

DeVries, T. J., T. Schwaiger, K. A. Beauchemin, and G. B. Penner. 2014. The duration of time that beef cattle are fed a high-grain diet affects feed sorting behavior both before and after acute ruminal acidosis. J. Anim. Sci. 92:1728-1737. https://doi.org/10.2527/ jas.2013-7252.

DeVries, T. J., M. A. G. von Keyserlingk, D. M. Weary, and K. A. Beauchemin. 2003. Measuring the feeding behavior of lactating dairy cows in early to peak lactation. J. Dairy Sci. 86:3354-3361. https://doi.org/10.3168/jds.S0022-0302(03)73938-1.

Drackley, J. 1999. Biology of dairy cows during the transition period: The final frontier? J. Dairy Sci. 82:2259-2273.

Eastridge, M. L. 2006. Major advances in applied dairy cattle nutrition. J. Dairy Sci. 89:1311-1323. https://doi.org/10.3168/jds .S0022-0302(06)72199-3.

Falk, M., A. Münger, and F. Dohme-Meier. 2016. Technical note: A comparison of reticular and ruminal $\mathrm{pH}$ monitored continuously with 2 measurement systems at different weeks of early lactation. J. Dairy Sci. 99:1951-1955. https://doi.org/10.3168/jds.2015-9725.

Felton, C. A., and T. J. DeVries. 2010. Effect of water addition to a total mixed ration on feed temperature, feed intake, sorting behavior, and milk production of dairy cows. J. Dairy Sci. 93:2651-2660. https://doi.org/10.3168/jds.2009-3009.

Fish, J. A., and T. J. DeVries. 2012. Short communication: Varying dietary dry matter concentration through water addition: Effect on nutrient intake and sorting of dairy cows in late lactation. J. Dairy Sci. 95:850-855. https://doi.org/10.3168/jds.2011-4509.

Goldhawk, C., N. Chapinal, D. M. Veira, D. M. Weary, and M. A. G. von Keyserlingk. 2009. Prepartum feeding behavior is an early indicator of subclinical ketosis. J. Dairy Sci. 92:4971-4977. https:/ /doi.org/10.3168/jds.2009-2242.

Grant, R. J., H. M. Dann, and M. E. Woolpert. 2015. Time required for adaptation of behavior, feed intake, and dietary digestibility in cattle. J. Dairy Sci. 98(E. Suppl. 2):312.

Greter, A. M., and T. J. DeVries. 2011. Effect of feeding amount on the feeding and sorting behavior of lactating dairy cattle. Can. J. Anim. Sci. 91:47-54. https://doi.org/10.4141/CJAS10067.

Grummer, R. R. 1995. Impact of changes in organic nutrient metabolism on feeding the transition dairy cow. J. Anim. Sci. 73:28202833. https://doi.org/10.2527/1995.7392820x.

Havekes, C. D., T. F. Duffield, A. J. Carpenter, and T. J. DeVries. 2020. Effects of wheat straw chop length in high-straw dry cow diets on intake, health, and performance of dairy cows across the transition period. J. Dairy Sci. 103:254-271. https://doi.org/10 .3168/jds.2019-17033.

Heinrichs, A. J. 2013. The Penn State Particle Separator. Extension publication DSE 2013-186. Pennsylvania State University, College Park.

Humer, E., K. Ghareeb, H. Harder, E. Mickdam, A. Khol-Parisini, and Q. Zebeli. 2015. Peripartal changes in reticuloruminal $\mathrm{pH}$ and temperature in dairy cows differing in the susceptibility to subacute rumen acidosis. J. Dairy Sci. 98:8788-8799. https://doi.org/ 10.3168/jds.2015-9893.

Janovick, N. A., Y. R. Boisclair, and J. K. Drackley. 2011. Prepartum dietary energy intake affects metabolism and health during the periparturient period in primiparous and multiparous Holstein cows. J. Dairy Sci. 94:1385-1400. https://doi.org/10.3168/jds.2010 -3303 .

Kanz, P., M. Drillich, D. Klein-Jöbstl, B. Mair, S. Borchardt, L. Meyer, I. Schwendenwein, and M. Iwersen. 2015. Suitability of capillary blood obtained by a minimally invasive lancet technique to detect subclinical ketosis in dairy cows by using 3 different electronic hand- held devices. J. Dairy Sci. 98:6108-6118. https://doi .org/10.3168/jds.2014-8957.

Khan, M. A., A. Bach, L. Castells, D. M. Weary, and M. A. G. von Keyserlingk. 2014. Effects of particle size and moisture levels in mixed rations on the feeding behavior of dairy heifers. Animal 8:1722-1727. https://doi.org/10.1017/S1751731114001487.

Kuhn, M. T., J. L. Hutchison, and H. D. Norman. 2006. Dry period length to maximize production across adjacent lactations and lifetime performance. J. Dairy Sci. 89:1713-1722. https://doi.org/10 .3168/jds.S0022-0302(06)72239-1.

Kleen, J. L., G. A. Hooijer, R. Rehage, and J. P. T. M. Noordhuizen. 2003. Subacute ruminal acidosis (SARA): A review. J. Vet. Med. A Physiol. Pathol. Clin. Med. 50:406-414. https://doi.org/10.1046/j .1439-0442.2003.00569.x.

Kok, A., J. Chen, B. Kemp, and A. T. M. van Knegsel. 2019. Review: Dry period length in dairy cows and consequences for metabolism and welfare and customised management strategies. Animal 13(S1):s42-s51. https://doi.org/10.1017/S1751731119001174.

Leonardi, C., and L. E. Armentano. 2003. Effect of quantity, quality, and length of alfalfa hay on selective consumption by dairy cows. J. Dairy Sci. 86:557-564. https://doi.org/10.3168/jds.S0022 -0302(03)73634-0.

Leonardi, C., F. Giannico, and L. E. Armentano. 2005. Effect of water addition on selective consumption (sorting) of dry diets by cattle. J. Dairy Sci. 88:1043-1049. https://doi.org/10.3168/jds.S0022 -0302(05)72772-7.

MacDonald, P. D. M., and P. E. J. Green. 1988. User's guide to program MIX: An interactive program for fitting mixtures of distributions. Icathus Data Systems, Hamilton, Canada.

Maulfair, D. D., and A. J. Heinrichs. 2013. Effects of varying forage particle size and fermentable carbohydrates on feed sorting, ruminal fermentation, and milk and component yields of dairy cows. J. Dairy Sci. 96:3085-3097. https://doi.org/10.3168/jds.2012-6048. 
Mertens, D. R. 1997. Creating a system for meeting the fiber requirements of dairy cows. J. Dairy Sci. 80:1463-1481. https://doi.org/ 10.3168/jds.S0022-0302(97)76075-2.

Miller-Cushon, E. K., and T. J. DeVries. 2009. Effect of dietary dry matter concentration on the sorting behavior of lactating dairy cows fed a total mixed ration. J. Dairy Sci. 92:3292-3298. https:/ /doi.org/10.3168/jds.2008-1772.

Miller-Cushon, E. K., and T. J. DeVries. 2017. Feed sorting in dairy cattle: Causes, consequences, and management. J. Dairy Sci. 100:4172-4183. https://doi.org/10.3168/jds.2016-11983.

Moore, S., and T. J. DeVries. 2018. Will dairy cows sort their diet in response to negative energy balance? J. Dairy Sci. 101(E. Suppl. 2): 171 .

Morris, T. R. 1999. Experimental Design and Analysis in Animal Sciences. CABI Publishing, New York, NY.

NRC. 2001. Nutrient Requirements of Dairy Cattle. 7th rev. ed. Natl. Acad. Press, Washington, DC.

Oelker, E. R., C. Reveneau, and J. L. Firkins. 2009. Interaction of molasses and monensin in alfalfa hay- or corn silage-based diets on rumen fermentation, total tract digestibility, and milk production by Holstein cows. J. Dairy Sci. 92:270-285. https://doi.org/ 10.3168/jds.2008-1432.

Park, A. F., J. M. DeFrain, E. C. Titgemeyer, and E. E. Ferdinand. 2001. Changes in rumen capacity of dairy cows during the periparturient period. Proceedings of the Dairy Day, 2001, Kansas State University, Manhattan. Kansas Agricultural Experiment Station and Cooperative Extension Service Publishers. https://doi.org/10 $.4148 / 2378-5977.3231$.

Schirmann, K., M. A. G. von Keyserlingk, D. M. Weary, D. M. Veira, and W. Heuwieser. 2009. Technical note: Validation of a system for monitoring rumination in dairy cows. J. Dairy Sci. 92:6052-6055. https://doi.org/10.3168/jds.2009-2361.

Schwaiger, T., K. A. Beauchemin, and G. B. Penner. 2013. The duration of time that beef cattle are fed a high-grain diet affects the recovery from a bout of ruminal acidosis: Dry matter intake and rumen fermentation. J. Anim. Sci. 91:5729-5742. https://doi.org/ 10.2527/jas.2013-6471.

Stone, W. C. 2004. Nutritional approaches to minimize subacute ruminal acidosis and laminitis in dairy cattle. J. Dairy Sci. 87:E13-E26. https://doi.org/10.3168/jds.S0022-0302(04)70057-0.

Tyrrell, H. F. and J. T. Reid. 1965. Prediction of the energy value of cow's milk. J. Dairy Sci. 48:1215-1223. https://doi.org/10.3168/ jds.S0022-0302(65)88430-2.

Wildman, E. E., G. M. Jones, P. E. Wagner, R. L. Boman, H. F. Troutt Jr., and T. N. Lesch. 1982. A dairy cow body condition scoring system and its relationship to selected production characteristics. J. Dairy Sci. 65:495-501. https://doi.org/10.3168/jds .S0022-0302(82)82223-6.

Wittrock, J. A., T. F. Duffield, and S. J. LeBlanc. 2013. Short communication: Validation of a point-of-care glucometer for use in dairy cows. J. Dairy Sci. 96:4514-4518. https://doi.org/10.3168/ jds.2012-6533.

\section{ORCIDS}

T. F. Duffield @ https://orcid.org/0000-0001-6035-4669

A. J. Carpenter $\odot$ https://orcid.org/0000-0002-9779-0779

T. J. DeVries @ https://orcid.org/0000-0001-9364-2456 